Jurnal Keperawatan Silampari

Volume 2, Nomor 1, Desember 2018

e-ISSN: 2581-1975

p-ISSN: 2597-7482

DOI: https://doi.org/10.31539/jks.v2i1.304

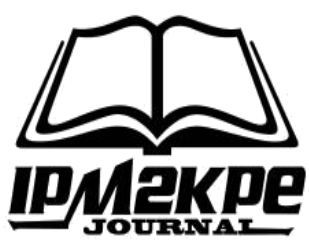

\title{
GAMBARAN MOTIVASI BELAJAR PADA SISWA PENGGUNA SMARTPHONE DI SMP NEGERI 4 GARUT
}

\author{
Sri Yekti Widadi ${ }^{1}$, Inge Ajeng Pramudita ${ }^{2}$ \\ Program Studi Ners, STIKES Karsa Husada Garut ${ }^{1,2}$ \\ sriyekti_s@yahoo.com ${ }^{1}$
}

\begin{abstract}
ABSTRAK
Tujuan dari penelitian adalah untuk mengetahui gambaran motivasi belajar pada siswa pengguna smartphone di SMP Negeri 4 Garut. Metode penelitian dalam penelitian ini adalah menggunakan metode penelitian deskriptif. Hasil penelitian setengah dari siswa $(50,6 \%)$ jarang menggunakan smartphone dan hampir setengah siswa $(41,6 \%)$ memiliki motivasi belajar cukup di SMP Negeri 4 Garut. Simpulan, Siswa yang jarang menggunakan smartphone memiliki motivasi belajar cukup dan siswa yang sering menggunakan smartphone memiliki motivasi belajar kurang.
\end{abstract}

Kata Kunci: Motivasi Belajar, Penggunaan Smartphone

\section{ABSTRACT}

The purpose of this research is to find out the description of learning motivation in smartphone users in SMP Negeri 4 Garut. The research method in this research is to use a descriptive research method. The results of the study half of the students $(50.6 \%)$ rarely use smartphones and almost half the students (41.6\%) have enough motivation to learn in SMP Negeri 4 Garut. Conclusion, Students who rarely use smartphones have sufficient learning motivation and students who often use smartphones have less learning motivation.

Keywords: Learning Motivation, Smartphone Use 


\section{PENDAHULUAN}

Penggunaan alat komunikasi seperti smartphone mengalami kemajuan sangat pesat mengikuti perkembangan teknologi dan informasi. Indonesia merupakan salah satu bangsa yang ikut terlibat dalam kemajuan media informasi dan teknologi (Ameliola, Nugraha, 2013). Badan Pusat Statistik (BPS) yang bekerja sama dengan Asosiasi Penyelenggara Jasa Internet Indonesia (APJII), berdasarkan hasil survei menyebutkan bahwa penggunaan internet di Indonesia sampai akhir tahun 2013 mencapai 71,19 juta orang, survei ini dilaksanakan pada 78 kabupaten/kota dan 33 provinsi, dengan diantaranya sembilan juta penggunakan ponsel dalam mengakses internet. (APJII, 2015), selain itu harga ponsel smartphone lebih terjangkau dan tersedia dengan berbagai keperluan. Meningkatnya penggunaan smartphone atau alat-alat yang dapat dengan mudah terkoneksi dengan internet ini, mengalami peningkatan dari waktu ke waktu.

Pengguna smartphone dan internet pada tahun 2016Anak-anak di Indonesia mulai menggunakan internet menurut Asosiasi Penyelenggara Internet Indonesia (APJII). Berdasarkan hasil statistik di Indonesia pengguna dilihat dari usia anak-anak berjumlah 132,7 juta. Pertumbuhan 51,8 persen dari survei APJII 2014 dengan mencatat 88 juta pengguna, angka smartphone dan internet tersebut mengalami kenaikan.

Survey yang dilakukan oleh mobility report ericsson, perkembangan perangkat mobile di Indonesia mencapai 5 juta pada kuartil pertama 2016, yang menjadikannya peringkat tiga di kawasan Asia Pasifik. Indonesia juga memiliki jumlah layanan smartphone yang hampir mendekati jumlah 100 juta di tahun 2015 dengan jumlah tertinggi di Asia Tenggara dan Oceania. Perkembangan tersebut akan mencapai pertumbuhan sebesar 250 juta langganan pada akhir 2021 (Yusra, Yeni, 2017 )

Fitur smartphone semakin maju dan berkembang terus sesuai kemajuan teknologi. Hal tersebut dapat menarik perhatian lebih untuk menggunakan smartphone yang semakin sering. Smartphone yang berkembang memberikan fasilitas-fasilitas yang selalu menarik dan dapat diadopsi nebjadi suatu perubahan gaya hidup. Hal tersebut menjadi suatu kekhawatiran pada pengguna smartphope dari kalangan dewasa maupu anak-anak. Menurut Backer (2010) smartphone adalah merupakan bentuk kecanggihan dari Wireless Mobile Device (WMD) yang dapat berguna seperti kerja komputer dengan menghasilkan bentuk-bentuk fitur-fitur seperti Personal Digital Assistent (PDA), akses internet,email,dan Global Positioning System (GPS). Smartphone merupakan telephone yang menyatukan kemampuan-kemampuan terdepan.

Berdasarkan karakteristik usia smartphone tidak hanya digunakan oleh orang dewasa atau lanjut usia (22 tahun keatas), remaja (12-21 tahun) saja, akan tetapi pada anak-anak (7-11 tahun), dan lebih ironisnya lagi digunakan untuk anak usia (3-6 tahun)Faktanya smartphone, yang seharusnya belum layak untuk menggunakan smartphone (Widiawati, Sugiman, 2014). Menurut hasil survei APJII pengguna internet 2016, pemblokiran situs tertentu masih jauh dari memuaskan, sebab 69,2 persen responden atau 91,8 juta menyatakan belum cukup puas, sedangkan yang menyatakan sudah memuaskan hanya 30,2 persen atau 40 juta pengguna. Ini cukup mengejutkan, anak dengan umur sekitar 10-16 tahun menggunakan smartphone sudah mengakses internet. Hal ini perlu mendapat perhatian khusus bagi orang tua khususnya agar lebih menyikapi secara bijak untuk menggunakan smartphone. (anak-anak usia 10-16 tahun) belum bermain di media sosial, mereka sering mengakses dengan menonton video, salah satunya di YouTube," ucap Jamal. Konten media sosial yang sering dikunjungi yaitu Facebook 54 persen (71,6 juta), Instagram 15 persen (19,9 juta), dan YouTube 11 
persen (14,5 juta). Pekerjaan rumah menjadikan peran keluarga agar menhjadikan internet sehat dan lebih bagus lagi dalam penggunaan smartphone. Karena, selama ini filter konten masih kurang memuaskan," ucap Ketua APJII (Jamalul Izza, 2016).

Upaya perlindungan dan pemenuhan hak anak dan remaja atas informasi harusnya memerlukan langkah-langkah strategis yang perlu didukung dan dilaksanakan bersama oleh semua elemen bangsa dan negara (Sunarto, 2011). Faktanya menunjukkan bahwa media sering menyajikan informasi yang justru dapat membahayakan anak dan remaja, baik fisik maupun mental.

Oleh karenanya, hak anak atas informasi (Pasal 17) merupakan bagian dari hak anak yang perlu dilindungi dan dipenuhi. Untuk tujuan itu, penyebarluasan bahanbahan yang bermanfaat dari segi sosial dan budaya melalui berbagai media sangat penting dan perlu dikendalikan. Penggunaan media di kalangan anak dan remaja perlu dilandasi dengan pemahaman dan kemampuan memilih dan memilah informasi serta cara pemanfaatannya, Undang-Undang Republik Indonesia Nomor 44 Tahun 2008 tentang Pornografi, pasal 17 Pemerintah dan Pemerintah Daerah wajib melakukan pencegahan pembuatan, penyebarluasan, dan penggunaan pornografi (Wibowo, 2011). Demikian juga akses anak terhadap informasi merupakan bagian dari hak-hak dasar mereka yang perlu mendapatkan perhatian serius dari semua pihak. Saat ini kebijakan pemerintah diarahkan kepada pengendalian arus informasi terutama pada anak-anak dan remaja. Sebagaimana ditegaskan dalam konvensi hak anak 1989, hak menyatakan pendapat dan hak untuk didengar (Pasal 12) Turnomo (2011) kebebasan berekspresi, termasuk untuk mencari, menerima, dan memberikan informasi (Pasal 13) merupakan bagian dari hak-hak dasar anak yang harus dilindungi (Wibowo, 2011).

Anak sudah tidak terlampaui subjektif lagi, gambaran pengertian mengenai dunia menjadi semakin sempurna, sebab. Pada saat ini anak tidak lagi banyak dikuasai oleh dorongan-dorongan endogen atau impuls-impuls intern dalam perbuatan dan fikirannya, akan tetapi lebih banyak dirangsang oleh stimuli dari luar (Kartono, 2012).

Smartphone merupakan telepon genggam dengan fungsi yang menyerupai komputer dan mempunyai kemampuan tingkat tinggi. Smartphone ini dapat disukai banyak orang untuk digunakan karena membuat seseorang merasa mudah menggunakan dan selalu terhubung dengan orang-orang yang tak peduli lagi berada di mana. Mungkin di kalangan anak-anak sendiri dapat menghabiskan waktu seharian menggunakan smartphone jika tidak ada kegiatan lain yang berhubungan dengan metabolisme tubuh, tak terkecuali para remaja (Sarwar, Soomro, 2013). Smartphone dapat melakukan hal yang sangat interaktif dan bisa jadi apapun dalam hal berkomunikasi. Berdasarkan paparan diatas anak dan remaja ditajutkan menjadi figur yang kurang berinteraksi dengan lingkungan sosial.

Pada usia anak-anak lebih banyak dirangsang oleh stimulus dari luar misalnya dalam konteks ini ketika terdapat satu anak yang menggunakan smartphone maka anak yang lain ingin memiliki smartphone untuk hal yang sama yaitu menggunakan smartphone untuk kelengkapan fasilitas dalam berhubungan dengan teman sebayanya, sehingga orang tua memberikan hadiah pada anaknya yaitu berupa smartphone (Kartono, 2012). Tidak sedikit anak-anak begitu menikmati penggunaan smartphone sehingga lupa belajar. Sebagaimana dari hasil penelitian saat ini pengguna smartphone terbanyak pada anak-anak usia 5-12 (Ameliola, Nugraha, 2013).

Namun orangtua terkadang tidak memperdulikan dampak penggunaan smartphone bagi anak-anak yang tidak terkontrol, seperti tidak jarang anak lupa belajar, sehingga mengganggu proses belajar. Menurunnya siswa untuk belajar dengan serius 
dipengaruhi dorongan dari siswa itu sendiri yang datangnya dari diri sendiri yaitu motivasi siswa tersebut. Motivasi akan menurun bila mana ada faktor luar yang kuat mempengaruhinya. Motivasi adalah semua termasuk daya penggerak psikis di dalam diri seseorang yang dapat menimbulkan suatu aktivitas, dan menjamin berlangsungnya suatu kegiatan tersebut dalam memberikan arah pada kegiatannya demi mencapai tujuan (Winkel, 2013).

Sebagaimana diungkapkan Widiana motivasi adalah salah satu dasar untuk membentuk suatu perilaku. Suatu perilaku memerlukan regulasi dari dalam individu maupun dari aturan atau norma yang diterapkan di luar individu tersebut, agar individu senantiasa dapat menunjukkan tindakan yang baik dari sudut pandang yang beragam. Ada individu yang mempunyai kontrol diri yang tinggi dan ada individu yang mempunyai kontrol diri yang rendah. Individu yang memiliki kontrol diri tinggi mampu melakukan perubahan informasi yang kurang baik menjadi agen utama dalam melakukan pengarahan dan mengatur perilaku yang membawa kepada konsekuensi positif (Widiana, 2013).

Kontrol diri negatif yang tidak dapat dikelola dengan baik dapat mempengaruhi motivasi yang buruk pula. Sebagaimana dari beberapa penelitian yang telah dilakukan seperti oleh Manumpil, dkk (2015) dalam jurnal keperawatan "Hubungan Penggunaan Gadget dengan Tingkat Prestasi Siswa Di SMA Negeri 9 Manado, disimpulkan terdapat hubungan penggunaan gadget dengan tingkat prestasi belajar siswa di SMA Negeri 9 Manado. Hal ini juga didukung oleh hasil penelitian Fadilah (2011) mengenai pengaruh penggunaan alat komunikasi handphone (HP) terhadap aktivitas belajar siswa SMP Negeri 66 Jakarta Selatan, didapat kesimpulan bahwa terdapat korelasi positif yang kuat atau tinggi antara penggunaan alat komunikasi handphone (HP) terhadap aktivitas belajar siswa di SMP Negeri 66 Jakarta Selatan.

Selanjutnya peneliti melakukan pengamatan di SMPN 4 Garut, karena SMPN 4 pengguna smartphone relatif banyak. Hasil ini dibuktikan dengan jumlah penggunaan smartphone di SMPN 4 sebanyak 47\% dari murid yang ada (742), di SMPN 5 sebanyak $42 \%$ dari murid yang ada (654) dan di SMPN 6 sebanyak 31\% dari murid yang ada (648), sehingga peneliti memilih melakukan penelitian di SMPN 4. Hasil wawancara di sekolah dasar di SMPN 4 Garut terhadap 8 orang siswa kelas VII dan kelas VIII, 3 orang mengemukakan bahwa smartphone adalah alat komunikasi yang penting terutama penyampaian informasi antara kelangsungan hubungan dengan orang tuanya, teman sebayanya, karena dia selalu menggunakannya untuk mengirim pesan kepada orang tua dan teman-temannya, atau untuk sekedar mengetahui kabar, dan berkenalan dengan teman baru. Namun diperoleh informasi juga 5 orang siswa lainnya sering menggunakan game online, BBM, Whatsapp, line dan instagram. Berdasarkan informasi dari wali kelasnya terdapat 5 orang yang prestasinya menurun.

Tujuan penelitian ini adalah untuk mengetahui gambaran motivasi belajar pada siswa pengguna smartphone di SMP Negeri 4 Garut. 


\section{METODE PENELITIAN}

Penelitian ini menggunakan rancangan jenis penelitian Deskriptif. Metode ini bertujuan untuk mendapatkan gambaran mengenai tanda-anda yang akan dilakukan penelitian sekarang ini. Setelahnya diketahui jawaban bagi penyelesaian masalah atau fenomena-fenomena yang ditemukan (Notoatmodjo, 2010). Variabel yang dikaji dalam penelitian adalah penggunaan smartphone dan motivasi belajar.

Populasi adalah merupakan setiap objek yang memiliki banyaknya dan ciri-ciri tertentu yang ditetapkan oleh peneliti (Sugiyono, 2013). Populasi dalam penelitian ini adalah seluruh murid kelas VII dan VIII yang berada di SMPN 4 Garut pada tahun 2017 sebanyak 742 siswa. Metode pengambilan sampel yang dilakukan dalam penelitian ini adalah purposive sampling yaitu dengan menentukan objek sampel dengan: Kriteria inklusi; anak kelas VII dan VIII, bersedia menjadi responden. Kriteria eksklusi; tidak mau menjadi responden, sakit, anak yang tidak hadir saat penelitian.

Pengambilan sampel dilakukan dengan rumus proporsional yang diadopsi dari Saryono (2010) dengan skala pengukuran kategorikal, sebanyak 89 siswa kelas VII dan VIII SMPN 4 Garut. Tahapan peneliti dalam melakukan penelitian terlebih dahulu mengadakan pendekatan kepada calon responden, menjelaskan maksud penelitian ini. Bilamana calon responden bersedia menjadi calon responden, peneliti meminta kesediaan calon responden untuk menandatangani format kesediaan menjadi responden (informed concent).

Langkah selanjutnya peneliti mengadakan penelitian dengan memberikan kuesioner mengenai motivasi. Selama pengisian kuesioner oleh responden, peneliti mendampingi dan memberikan penjelasan tambahan bila ada yang belum dipahami. Untuk mendapatkan data penggunaan smartphone peneliti melakukan pengumpulan data melalui tanya jawab dengan siswa yaitu menanyakan membawa smartphone atau tidak. Selanjutnya data hasil penelitian dari kuesioner dicatat di lembar penelitan untuk diproses lebih lanjut.

Uji validitas yang digunakan dalam penelitian ini merupaka valditas isi. Hal tersebut ditujukan agar penelitian dapat menghasilkan data yang komprehensif dan penelitian relevan dengan tujuan penelian. Proses validitas dilakukan dengan berkonsultasi dan persetujuan oleh dosen pembimbing.

Uji validitas dan reliabilitas dilakukan di SMPN 6 Garut dengan mengambil sampel sebanyak 20 orang murid.Hasil uji validitas dari 18 pertanyaan diperoleh $\mathrm{r}$ hitung terkecil $=0,940$, sedangkan $r$ tabel $=0,514$, $r$ hitung $>r$ tabel, disimpulkan semua pertanyaan valid untuk digunakan pada penelitian.

Hasil uji reliabilitas, diperoleh $\mathrm{r}$ hitung $=0,998, \mathrm{r}$ tabel $=0,544, \mathrm{r}$ hitung $>\mathrm{r}$ tabel, disimpulkan semua pertanyaan reliabel untuk digunakan pada penelitian.

Pengumpulan data penelitian telah dilakukan di SMPN 4 Garut, waktu pengumpulan data dilakukan pada bulan Juli-Agustus 2017. 


\section{HASIL PENELITIAN}

Berdasarkan hasil penelitian dan pengolahan data pada penelitian ini, mengenai penggunaan smartphone di SMP Negeri 4 Garut dapat dilihat pada tabel seperti tersebut di bawah ini :

Tabel. 1

Distribusi Frekuensi Penggunaan Smartphone

\begin{tabular}{lll}
\hline Penggunaan Smartphone & F & $\%$ \\
\hline Sering & 44 & 49,4 \\
\hline Jarang & 45 & 50,6 \\
\hline Jumlah & 89 & 100 \\
\hline
\end{tabular}

Berdasarkan hasil penelitian sesuai tabel diatas diketahui bahwa, setengah dari siswa $(50,6 \%)$ di SMP Negeri 4 Garut jarang menggunakan smartphone dan hampir setengahnya siswa $(49,4 \%)$ sering.

Tabel. 2

Distribusi Frekuensi Motivasi Belajar Siswa

\begin{tabular}{lll}
\hline Motivasi & F & $\%$ \\
\hline Baik & 20 & 22,5 \\
Cukup & 37 & 41,6 \\
Kurang & 32 & 36,0 \\
Jumlah & 89 & 100 \\
\hline
\end{tabular}

Berdasarkan hasil penelitian sesuai tabel diatas diketahui bahwa, sebagian besar siswa $(41,6 \%)$ memiliki motivasi cukup di SMP Negeri 4.

Tabel. 3

Tabel Silang Penggunaan Smartphone dengan Motivasi Belajar

\begin{tabular}{lcccccccc}
\hline Penggunaan & \multicolumn{3}{l}{ Motivasi Belajar } & \multicolumn{3}{l}{ Kotal } \\
\cline { 2 - 10 } Smartphone & \multicolumn{2}{l}{ Baik } & \multicolumn{2}{l}{ Cukup } & \multicolumn{2}{c}{ Kurang } & \\
\cline { 2 - 10 } & F & $\%$ & F & $\%$ & F & $\%$ & F & $\%$ \\
\hline Jarang & 14 & 31,8 & 21 & 47,7 & 9 & 20,5 & 44 & 100 \\
\hline Sering & 6 & 13,3 & 16 & 35,6 & 23 & 51,1 & 45 & 100 \\
\hline
\end{tabular}

Berdasarkan tabel diatas dapat diketahui bahwa proporsi penggunaan smartphone sering lebih dari setengah siswa $(51,1 \%)$ memiliki motivasi belajar kurang. 


\section{PEMBAHASAN}

\section{Penggunaan Smartphone}

Berdasarkan hasil penelitian sesuai tabel diatas diketahui bahwa, setengah dari siswa $(50,6 \%)$ di SMP Negeri 4 Garut jarang menggunakan smartphone dan hampir setengahnya siswa $(49,4)$ sering. Melihat perkembangan saat ini, mulai dari yang sederhana sampai perkembangan yang terakhir ini menunjukkan bahwa smartphone mempunyai fungsi yang cukup kompleks. Bahkan peran smartphone dalam kehidupan modern ini tidak dapat disatukandengan aktivitas harian dalam kehidupan sekarang ini, ibarat tidak ada hidup jika tidak ada smartphone (Nurdin, 2014).

Penelitian ini memperlihatkan bahwa setengah dari siswa (50,6\%) di SMP Negeri 4 Garut jarang menggunakan smartphone dan hampir setengahnya siswa $(49,4)$ sering. Melihat hasil ini masih ada 49\% siswa sering menggunakan smartphone. Bagi anakanak, smartphone dapat digunakan sebagai alat bermain game. Mulai dari game online hingga game statis. Banyak anak SMP, baik di desa maupun di kota sudah mampu mengoperasikan smartphone dan bermain game di smartphone. Smartphone bukan merupakan barang mewah lagi. Bahkan peran smartphone dalam kehidupan modern ini tidak dapat dipisahkan dari aktivitas sehari-hari, ibarat tidak ada hidup jika tidak ada smartphone.

Perkembangan peran smartphone yang tidak dapat lepas dari gaya hidup aktivitas manusia sekarang ini, nampaknya dipengaruhi oleh faktor-faktor tertentu, antara lain: Pertama, kebutuhan komunikasi. Pada era sekarang ini komunikasi merupakan hal yang utama, dan jarak tidak menjadi hambatan dalam melakukan informasi dua arah antara individu satu dengan individu yang lainnya. Jadi rata-rata orang yang hidup di komunitas serba modern ini harus mempunyai smartphone. Maka dari itu, dapat dikatakan bahwa ponsel mempunyai peran yang signifikan dalam kehidupan manusia pada era sekarang. Kedua, trend masa kini. Faktor ini nampaknya dilatar belakangi adanya gengsi. Maka orang yang terpengaruh oleh faktor ini adalah para anak muda yang memburu pergaulan dan gengsi. Mereka rata-rata mempunyai smartphone model terbaru dan bagus-bagus. Bahkan uang saku mereka yang mereka tabung, diambil untuk membeli smartphone yang model terbaru. Ketiga, tingkat ekonomi. Seseorang yang tingkat ekonominya menengah ke atas, tidak segan-segan untuk membeli smartphone yang bagus yang sesuai dengan trend masa kini.

Namun perlu diperhatikan bahwa dampak dari penggunaan smartphone ini cukup tinggi, sebagaimana dikemukakan Widyawati (2014) komunikasi smartphone sudah dengan nyata dapat menurunkan keinginan untuk membaca, pada masyarakat modernsekarang ini, seperti buku, majalah dan koran. Didukung oleh data majalah Komputer Aktif (no. 50/26 Maret 2014) berdasarkan survei Siemens Mobile Lifestyle III bahwa terdapat 60 persen remaja usia 10-19 tahun dan pasca remaja lebih menyukai mengirim dan membaca SMS daripada membaca buku, majalah atau koran. Berdasarkan hal tersebut, komunikasi melalui smartphone seperti pengiriman SMS ternyata dapat berakibat berdampak buruk dalam menurunkan minat baca masyarakat. SMS dalam hal ini lebih berfungsi sebagai hiburan saja. Kemungkinan dapat dikatakan bahwa budaya membaca yang sudah terancam dengan budaya dengar dan lihat diancam lagi oleh budaya mengirim SMS.

Diungkapkan oleh Pekerti A. B. (2013) Melalui smartphone aksi pornografi semakin merajai benak kaum remaja Indonesia. penyalahgunaan fasilitas dari smartphone juga membawa dampak buruk bagi kaum remaja Indonesia. Hal ini dapat mengakibatkan masa depan bangsa Indonesia terpuruk jika dampak buruh smartphone 
lebih banyak digunakan terutama oleh anak dan remaja yang merupakan masa depan bangsa Indonesia.

Contoh dampak buruk adalah fenomena yang marak terjadi di kalangan remaja bahkan anak-anak yaitu, merekam aksi porno, mengambil atau dengan sengaja memotret gambar porno untuk kemudian disebarkan ke smartphone lain adalah. Dengan fasilitas yang dimiliki oleh smartphone, maka di zaman yang serba canggih dan modern ini segalanya bisa dilakukan dengan duduk di tempat tanpa perlu beranjak dari tempat duduk dan meninggalkan aktivitas seseorang. Secara psikologis kerugian yang diakibatkan dari penggunaan telepon seluler atau smartphone adalah manusia menjadi malas untuk bersosialisasi dengan teman dan lingkungan sekitar.

Hal lain yang dapat mempengaruhi pada siswa adalah malas belajar, karena sering menggunakan smartphone. Sering atau jarangnya penggunaan smartphone tergantung lama pemakaian selama sehari. Sebagaimana hasil penelitian Nielson (2013) yang mengatakan penggunaan rata-rata smartphone setiap hari secara normal adalah 3 jam, bilamana lebih dari 3 jam dinyatakan sebagai penggunaan smartphone sering. Sebagaimana hasil penelitian ini setengah dari siswa di SMP Negeri 4 Garut jarang menggunakan smartphone dan hampir setengahnya siswa sering.

Penggunaan smartphone yang sering tentunya mempengaruhi proses belajar pengguna. Hal ini diperkuat oleh pernyataan Nurdin (2014) bahwa penggunaan smartphone mempengaruhi terhadap minat baca siswa. Hal ini juga didukung oleh hasil penelitian Fadilah (2015) mengenai pengaruh penggunaan alat komunikasi handphone (hp) terhadap aktivitas belajar siswa SMP Negeri 66 Jakarta Selatan, yaitu disimpulkan terdapat korelasi positif yang kuat atau tinggi antara penggunaan alat komunikasi handphone (HP) terhadap aktivitas belajar siswa di SMP Negeri 66 Jakarta selatan. Demikian juga hasil penelitian Manumpil, dkk (2015) disimpulkan ada hubungan penggunaan gadget dengan tingkat prestasi belajar siswa di SMA Negeri 9 Manado dalam jurnal keperawatan "hubungan penggunaan gadget dengan tingkat prestasi siswa di SMA Negeri 9 Manado.

Perlu diperhatikan sebagaimana diulas diatas penggunaan smartphone selain menggangu minat belajardengan menggunakan smartphone yang terlalu sering dapat mengganggu kesehatan. Perkembangan kemampuan fisik dan kognitif pada masa sekolah ini lebih cepat jika dibandingkan dengan masa usia prasekolah. Teknologi yang semakin tinggi dan semakin pesat, terdapat banyak anak-anak terutama pada anak yang berusia 13 hingga 15 tahun lebih menyukai bermain dengan teknologi baru seperti smartphone, playstation, game online, , tablet ataupun ipad. Hal ini memang memiliki sisi positif dan negatif terhadap dampak perkembangan pada anak, terutama anak usia 5-12 tahun karena tugas perkembangan anak harus optimal sesuai usia.Perkembangan masa anak-anak adalah masa keemasan dimana anak-anak berada dalam masa bermain serta belajar terhadap apa yang belum diketahuinya. Namun dampak dari adanya perkembangan tekonologi ini anak lebih menyukai ke permainan dan komunikasi yang mudah dan menyenangkan untuk dilakukan (Patmonodewo, 2011). Awal penggunaan smartphone anak menjadi sulit diajak berkomunikasi, tidak memperdulikan lingkungan sekitar, sering suasana hati yang sedang buruk dan kurang mendengarkan nasihat orang tua, hal ini menyebabkan mereka menjadi malas untuk beraktivitas, serta dapat berpengaruh buruk bagi kemampuan sosialisasi anak dengan lingkungan sekitar Selain berdampak terhadap perkembangan anak, smartphone juga memiliki dampak terhadap kesehatan. 
Adanya teknologi komunikasi berupa handphone atau smartphone yang semakin maju dan semakin pesat tidak dapat kita tinggalkan. Masyarakat umumnya tidak ada yang dapat secara tegas menolak adanya teknologi yang digunakan oleh masyarakat dari berbagai kalangan tersebut. Masalah dengan adanya smartphone di masyarakat dengan upaya dan cara yang kita lakukan untuk menolak adanya teknologi komunikasi tersebut malah justru akan semakin membuat kita dilematis. Secara tidak langsung memang teknologi komunikasi membawa berbagai keuntungan bagi mereka penggunanya. Namun dibalik keuntungan yang didapatkan tersebut ternyata didapatkan banyak kerugian yang menyebabkan dampak buruk bagi psikologis dan kesehatan penggunaan teknologi komunikasi itu sendiri (Fidler, 2012). Berdasarkan paparan tersebut hal ini tentunya dapat membahayakan masa depan bangsa Indonesia terutama usia anak dan remaja sebagai aset masa depan bangsa jika dampak buruk lebih besar dari pada dampak positifnya.

Smartphone dapat memberikan dua dampak dalam kehidupan manusia seharihari. Pertama adalah dampak yang positif, dimana ponsel membawa keuntungan bagi manusia. Kedua adalah dampak negatif, dimana smartphone membawa kerugian bagi manusia. Dengan adanya smartphone berbagai keuntungan relatif yang dirasakan dari telepon seluler tanpa kabel yang mengungguli telepon kabel dan telepon-radio kian bertambah karena mobilitas dan efisiensinya yang lebih besar. Dapat terlihat nyata bahwa jelas teknologi komunikasi memberikan keuntungan yang sangat besar bagi penggunanya terutama dalam hal berkomunikasi (komunikasi tidak lagi rumit seperti dulu). Berbeda dengan yang disambungkan pada jalur telepon disebuah gedung atau telepon Berbagai percobaan telah dilakukan oleh para ahli untuk mengatahui pengaruhradiasi ponsel bagi kesehatan. Dr. Lennart Hardell, seorang peneliti Swedia, mengemukakan bahwa penggunaan ponsel selama satu jam per hari dalam kurun waktu sepuluh tahun dapat meningkatkan resiko terkena tumor otak (Lienita, 2009). Berdasarkan penelitian tersebut, pada penggunaan jangka pendek, radiasi ponsel memangtidak menyebabkan penyakit yang berarti. Tetapi pada penggunaan jangka panjang,radiasi ponsel dapat memicu penyakit acoustic neuroma (sejenis tumor otak). Hal ini dapat mempengaruhi kondisi kesehatan seseorang.

Oleh karena itu pengendalian penggunaan smartphone perlu terus diupayakan terutama bagi siswa, karena dampak penggunaan yang tidak terkedali anak menjadi malas belajar yang akibatnya motivasi belajar siswapun menurun dan hasil belajar menjadi tidak baik. Peran guru di sekolah perlu ditingkatkan untuk pengendalian penggunaan smartphone, demikian juga peran orangtua untuk selalu mengawasi anaknya di rumah serta tidak selalu harus memberikan smartphone yang terlalu mudah untuk mengakses segala apa yang diinginkan oleh anak, batasi dengan pengawasan.

Tugas utama perawat anak adalah optimalisasi tumbuh kembang anak sesuai dengan usianya, perkembangan masa usia prasekolah tentunya berbeda dengan masa sekolah, pada masa sekolah ini perkembangan lebih cepat dalam kemampuan fisik dan kognitif. Dengan adanya smartphone, perubahan teknologi semakin pesat, banyak anak-anak terutama pada anak yang berusia 13 hingga 15 tahun lebih senang bermain dengan teknologi baru seperti smartphone, playstation, game online, tablet ataupun ipad. Hal ini memang memiliki dampak positif dan dampak negatif terhadap dampak perkembangan teknologi untuk anak usia 5-12 tahun. Padahal masa anak-anak adalah masa golden period dimana anak-anak berada dalam masa bermain serta belajar terhadap apa yang belum diketahuinya. Namun dampak dari adanya perkembangan tekonologi ini anak lebih menyukai ke permainan dan komunikasi yang mudah dan 
menyenangkan untuk dilakukan (Patmonodewo, 2011). Peran orang tua, guru, dan anak sendiri tetap harus diperhatikan dalam penggunaan smartphone.

Sebagai orang tua yang mendidik remaja laki-laki, berikut sejumlah hal yang perlu dilakukan: kurangi penggunaan gadget, ajarkan penggunaan gadget untuk keperluan pembelajaran dan komunikasi positif, arahkan pada aktivitas yang menjadi minatnya (olah raga, seni, jurnalis, dll), lakukan komunikasi efektif. Kaitkan agama dalam aktivitas sehari-hari (bukan sekedar rutinitas ibadah). Selain itu, ada sejumlah hal yang perlu ditinggalkan oleh orang tua dalam mendidik anak. Tujuannya agar tumbuh kembang anak tetap optimal dan berlangsung dengan baik.

Orangtua harus tegas dengan memperbolehkan anak menggunakan smartphone, itu pun waktunya harus dibatasi. Orangtua bisa memberikan waktu untuk anak bermain smartphone yakni tidak boleh dilakukan lebih dari 3 jam setelah makan siang di akhir pekan dengan catatan.

\section{Motivasi Belajar}

Berdasarkan hasil penelitian sesuai tabel 1 diatas diketahui bahwa, hampir setengah siswa $(41,6 \%)$ di SMP Negeri 4 Garut memiliki motivasi belajar cukup. Motivasi merupakan dorongan yang datang dari diri sendiri, motivasi dapat membentuk langkah seseorang untuk bertindak. Demikian pula dalam belajar, bila motivasi kurang, maka pelajar cenerung malas untuk belajar. Sebagaimana diungkapkan Purwanto (2014) motivasi belajar adalah keinginan individu supaya belajar agar lebih baik. Berdasarkan hal tersebut dapat disimpulkan bahwa motivasi belajar merupakan hal sangat penting sekali dimiliki oleh siswa, karena dengan adanya motivasi intrinsik dalam diri siswa dan siswi, ketika mengikuti proses belajar mengajar maka hasil belajarnya akan lebih optimal. Makin baik dan tepat motivasi yang diberikan maka makin besar pula keberhasilan pelajaran.

Pelayanan bimbingan dan konseling, kehadiran guru dapat mengetahui kondisi dan masalah siswa dan siswi. Di samping itu, guru juga bisa melakukan pembinaan terhadap siswa tersebut (Sardiman, 2014). Motivasi agar selalu menentukan intensitas usaha belajar siswa. Oleh karena itu, guru sebagai pendidik harus mampu meningkatkan motivasi belajar siswa, salah satunya dengan melalui pelayanan bimbingan dan konseling.

Seperti di lingkungan sekolah penting untuk meningkatkan motivasi belajar siwa dan siswi di sekolah melalui kegiatan program-program yang ditawarkan oleh sekolah, oleh karena itu motivasi belajar sangat penting untuk mencapai kesuksesan belajar. Hasil penelitian ini memperlihatkan bahwa siswa SMPN 4 Garut memiliki motivasi belajar cukup baik. Kondisi ini perlu terus dipertahankan oleh pihak sekolah, karena motivasi itu penting dalam proses belajar. Siswa akan beprestasi bilamana memiliki motivasi tinggi. Dalam hal belajar motivasi memiliki pengertian sebagai keseluruhan daya penggerak dalam diri sisw dan siswi untuk melakukan serangkaian kegiatan belajar guna mencapai tujuan yang telah ditetapkan. Tugas guru adalah membangkitkan motivasi anak sehingga ia mau melakukan serangkaian kegiatan belajar.

Motivasi belajar dibedakan kedalam dua golongan, yaitu motivasi intrinsik dan motivasi ekstrinsik. Pada motivasi intrinsik "tidak ada sasaran tertentu, dan karenanya akan lebih sesuai dengan dorongan asli dan yang murni untuk mengetahui serta melakukan sesuatu (aktivitas)". Sebagai contoh seseorang yang menyukai membaca, tidak perlu ada yang menyuruh atau melakukannya, seseorang yang sudah rajin mencari buku-buku untuk dibacanya, demikian pula sebaliknya (Sardiman, 2014). Motivasi 
intrinsik lebih menekankan pada faktor dari dalam diri individu sendiri, motif-motif yang menjadi aktif atau berfungsinya tidak memerlukan aktivitas yang dirangsang dari luar, karena dalam diri setiap individu sudah ada dukungan untuk melakukan sesuatu. Dibuktikan juga dari hasil penelitian ini dilihat dari analisis tabel silang diketahui bahwa proporsi penggunaan smartphone sering lebih dari setengah siswa $(51,1 \%)$ memiliki motivasi belajar kurang.

Seorang pelajar yang belajarnya tidak bersungguh-sungguh, dan tidak teratur, semaunya sendiri, asal-asalan, waktunya tidak menentu, tidak tuntas, tidak terusmenerus dan tidak berkesinambungan, baik ditambah dengan sering menggunakan smartphone untuk kegiatan yang tidak produktif atau sekedar main-main baik di sekolah maupun di rumah berarti ia tidak memiliki motivasi yang tinggi untuk belajar, sehingga individu yang bersangkutan tidak dapat membiasakan diri untuk belajar yang efektif, menjadikan sasaran belajarnya tidak tercapai. Sebaliknya jika dilakukan dengan waktu yang teratur dan baik akan dapat berperan dalam membantu keberhasilan seorang siswa dalam menuntut ilmu.

Motivasi ekstrinsik dapat diartikan sebagai motivasi yang dihasilkan diluar perbuatan itu sendiri misalnya dorongan yang datang dari orang tua, guru, teman-teman dan anggota masyarakat yang berupa hadiah, pujian, penghargaan maupun hukuman. Motivasi ektrinsik menurut Sardiman A.M. adalah "motif-motif yang aktif dan dapat berfungsi karena adanya perangsang dari luar" (Sardiman, 2014). Dalam proses pembelajaran tidak hanya memperhatikan kondisi internal dalam individu siswa saja akan tetapi juga lebih memperhatikan berbagai aspek lainnya seperti, aspek sosial yang meliputi berbagai lingkungan seperti, lingkungan keluarga, sekolah, masyarakat dan teman, seperti aspek budaya dan adat istiadat serta aspek lingkungan fisik, misalnya kondisi rumah dan suhu udara.

Hal-hal yang dapat menimbulkan motivasi ekstrinsik ialah: 1) Fasilitas; Fasilitas dapat menimbulkan pendorong bagi siswa dan siswi agar belajar lebih baik. 2) Hukuman; Hukuman walau bagaimanapun merupakan alat pendidikan yang tidak menyenangkan, namun demikian dapat juga menjadi alat motivasi, alat pendorong untuk membuat siswa dan siswi lebih meningkatkan proses belajar. Agar siswa. tersebut tidak lagi memperoleh hukuman. 3) Kompetisi atau persaingan; Dengan hadirnya persaingan maka dengan sendirinya akan menjadi faktor dukungan bagi siswa dan siswi untuk lebih giat belajar supaya tidak kalah bersaing dengan teman-temannya (Indrakusuma, 2014). Berdasarkan dari uraian di atas, baik motivasi intrinsik mapun motivasi ekstrinsik perlu digunakan dalam proses belajar mengajar. Motivasi sangat besar untuk diperlukan agar berfungsi meningkatkan semangat dalam belajar, kadangkala para siswa sering kali belum memahami untuk apa siswa dan siswi belajar hal-hal yang diberikan oleh sekolah. Dengan adanya motivasi, siswa dapat meningkatkan aktivitas dan inisiatif, serta dapat mengarahkan dan memelihara kerajinan dalam melakukan proses kegiatan belajar. Karena itu motivasi terhadap pelajaran di sekolah perlu lebih dibangkitkan oleh guru sehingga para siswa mau dan ingin belajar.

Sejalan dengan pendapat dari Usman (2012) dalam hal belajar motivasi merupakan keseluruhan daya penggerak dalam diri siswa untuk melakukan serangkaian kegiatan belajar untuk mencapai tujuan yang telah ditetapkan. Tugas dan peran guru adalah meningkatkan dan membangkitkan motivasi siswa dan siswi sehingga siswa dan siswimau melakukan serangkaian kegiatan belajar. Sebagaimana telah kita ketahui bahwa motivasi perupakan variabel pendukung yang dapat digunakan untuk menggerakan berbagai faktor-faktor tertentu dalam memanager, membangkitkan, 
mempertahankan dan menyalurkan tingkah laku menuju suatu tujuan tertentu. Hal ini diperkuat oleh hasil penelitian Hamid (2013) mengenai hubungan antara motivasi dengan prestasi belajar ekonomi siswa kelas VIII SMP Negeri 2 Kabupaten Bireuen, terdapat korelasi yang signifikan antara motivasi dengan prestasi belajar siswa dalam mempelajari bidang studi pendidikan, walaupun tingkat korelasinya tergolong lemah atau rendah. Demikian pula hasil penelitian Yusmahadi (2015) mengenai hubungan motivasi dengan hasil belajar siswa di SMP Negeri 22 Kota Jambi, dihasilkan siswa yang memiliki motivasi belajar tinggi akan menghasilkan capaian hasil belajar yang tinggi juga. Sedangkan siswa yang memiliki motivasi belajar rendah tentunya akan memiliki hasil yang rendah juga.

Hasil analisis pada penelitian ini memperlihatkan bahwa motivasi belajar siswa SMPN 4 cukup, hal ini sesuai hasil observasi peneliti dilapangan yang memperlihatkan bahwa siswa tekun dalam belajar karena didukung oleh peraturan ketat, lingkungan yang baik serta perhatian guru cukup baik, walaupun ada siswa yang motivasi belajarnya masih kurang karena masih banyak pada saat jam istirahat ada yang bermain smartphone yang kemungkinan besar akan mempengaruhi proses belajar.

\section{SIMPULAN}

Sesuai dengan hasil pembahasan mengenai Gambaran Motivasi Belajar Pada Siswa Pengguna Smartphone di SMP Negeri 4 Garut, dapat diambil kesimpulan hampir setengah siswa di SMP Negeri 4 Garut memiliki motivasi belajar cukup, setengah dari siswa di SMP Negeri 4 Garut jarang menggunakan smartphone.

\section{SARAN}

1. Bagi SMPN 4. Melihat hasil penelitian ini masih terdapat siswa yang sering menggunakan smartphone, untuk itu agar dipantau dan diarahkan untuk tidak digunakan selama belajar di sekolah dengan pemeriksaan kepada siswa secara ketat.

2. Bagi Guru. Diharapkan para guru untuk turut mengawasi penggunaan smartphone secara ketat selama belajar di sekolah.

3. Bagi perawat. Agar memberikan pendidikan kesehatan kepada anak sekolah dan orang tua untuk mengawasi penggunaan smartphone dan dampak bagi perkembangan serta pertumbuhan kesehatan anak.

4. Bagi Peneliti Selanjutnya. Bagi peneliti selanjutnya, disarankan untuk melakukan penelitian yang berkaitan dengan dampak dari penggunaan smartphone terhadap hasil belajar, faktor-faktor yang mempengaruhi orangtua memberikan smartphone kepada siswa SMP. 


\section{DAFTAR PUSTAKA}

Ameliola, S., Nugraha, D. H. (2013). Perkembangan Media Informasi dan Teknologi terhadap Anak dalam Era Globalisasi. Malang: Universitas Brawijaya

APJII. (2015). Indonesia Internet Users. Laporan Asosiasi Penyelenggara Jasa

Backer, E. (2010). Using Smartphone and Facebook in a Major Assessment: The Student Experience. E Journal. Australia: University of Balla Consumers. tersedia dalam http://www.scribd.com/doc/71370794/The-digital-media-andhabits-attitudes-of-South-East.pdf. Asian-Consumers.pdf diakses pada tanggal 20 Mei 2013

Fidler, R. (2011). Mediamorfosis. Yogyakarata: Bentang Budaya

Hamid, M. (2013). Hubungan Antara Motivasi dengan Prestasi Belajar Ekonomi

Indrakusuma, A. D. (2014). Pengantar Ilmu Pendidikan. Surabaya: Usaha Nasional

Internet Indonesia. Diakses pada 1 April 2015, dari http://www.apjii.or.id/v2/read/page/halaman-data/9/statistik.html

Jamalul, I, Haryanto. (2016). Data Internet Indonesia, Pengguna Anak-anak Mengejutkan. http://teknologi.news.viva.co.id/news/read/838794-data internet indonesia- pengguna-anak-anak-mengejutkan [Dakses :11/04/17]

Kartono, K.(2012). Psikologi Anak(Psikologi Perkembangan). Bandung: Mandar Maju

Lienita. (2009). Dampak Radiasi Ponsel bagi Kesehatan. Makalah. Teknik Informatika Institut Teknologi Telkom Bandung

Nielsen. (2011). The Digital Media and Habits Attitudes of South East Asian

Notoatmodjo. (2010). Metodologi Penelitian Kesehatan. Jakarta: PT. Rineka Cipta

Nurdin, A. (2013). Pengantar Ilmu Komunikasi. Sidoarjo: CV. Mitra Media Nusantara

Patmonodewo, S. (2011). Buku Ajar Pendidikan Prasekolah. Jakarta: Departemen Pendidikan dan Kebudayaan Direktorat Jenderal Pendidikan Tinggi Proyek Pendidikan Tenaga Akademik

Pekerti, A. B. (2013). Pengaruh Jejaring Sosial terhadap Kelakuan seseorang. Semarang: Universitas Negeri semarang

Purwanto, N. (2014). Psikologi Pendidikan. Bandung: Rosda Karya

Rahardjo, T (2011). Isu-isu Teoritis Media Sosial, dalam Junaedi

Sardiman. (2014). Interaksi dan Motivasi Belajar Mengajar. Jakarta: PT. Raja Grafindo Persada

Sarwar, M., Soomro, Tariq, R. (2013). Impact of Smartphone's on Society. Siswa Kelas VIII SMP Negeri 2 Jangka Kabupaten Bireuen. Universitas Al Muslim

Sugiyono. (2013). Statistika untuk Penelitian. Bandung: Alfabeta

Sunarto, K. (2011. Pengantar Sosiologi. Yogyakarta: Yayasan Obor Indonesia

Wibowo. (2011). Dasar Dasar Inormasi dan Pengendaliannya. Jakarta: PT. Raja Grafindo Persada

Widiana, A. A. \& Nugraheni, H. (2013). Hubungan antara Pola Asuh Demokratis dengan Kemandirian pada Remaja. Jurnal Psikohumanika, 1(1)

Widiantoro, F. (2011). Fungsi Ponsel Bagi Orang Indonesia. Diakses pada tanggal 2 Februari 2017 dari http://inet.detik.com/ read/2010/03/06/113319/1312621/317/5fungsi-ponsel-bagi-orang indonesia

Widiawati, I., Sugiman, H, \& Edy. (2014). Pengaruh Gadget terhadap Daya Kembang Anak. Jakarta. Universitas Budi Luhur. E-journal Keperawatan, 6, 1-6

Winkel. (2011). Psikologi Pengajaran. Yogyakarta: Media Abadi 
Yusmahadi. (2015). Hubungan Motivasi dengan Hasil Belajar Siswa di SMP Negeri 22 Kota Jambi. Program Studi Bimbingan Konseling Jurusan Ilmu Pendidikan Universitas Jambi

Yusra,Y. (2017). Ericsson : Pengguna Smartphone di Indonesia 